This item was submitted to Loughborough's Research Repository by the author.

Items in Figshare are protected by copyright, with all rights reserved, unless otherwise indicated.

\title{
Export strategic orientation-performance relationship: Examination of its enabling and disenabling boundary conditions
}

\section{PLEASE CITE THE PUBLISHED VERSION}

http://dx.doi.org/10.1016/j.jbusres.2016.04.078

\section{PUBLISHER}

(C) Elsevier

\section{VERSION}

AM (Accepted Manuscript)

\section{PUBLISHER STATEMENT}

This work is made available according to the conditions of the Creative Commons Attribution-NonCommercialNoDerivatives 4.0 International (CC BY-NC-ND 4.0) licence. Full details of this licence are available at: https://creativecommons.org/licenses/by-nc-nd/4.0/

\section{LICENCE}

CC BY-NC-ND 4.0

\section{REPOSITORY RECORD}

Cadogan, John W., Nathaniel Boso, Vicky Story, and Ogechi Adeola. 2019. "Export Strategic Orientationperformance Relationship: Examination of Its Enabling and Disenabling Boundary Conditions". figshare. https://hdl.handle.net/2134/21875. 
Export strategic orientation-performance relationship: Examination of its enabling and disenabling boundary conditions 次

This study finds that the form of relationship between export strategies entrepreneurial orientation (EO) and export market orientation (MO) - and export sales performance is curvilinear and dependent on levels of intra-firmresource coordination capabilities. Findings fromprimary data drawn fromnewinternational ventures reveal that increased changes in combined $\mathrm{EO}$ and $\mathrm{MO}$ strategies lead to decreases in export sales performance. Results further indicate thatwhen levels of resource coordination flexibility andMOare higher the effect of EO on performance is strengthened. However, when levels ofMO increase in magnitude along with higher levels of resource coordination flexibility, the levels of sales performance decrease. A natural conclusion to drawis that new international ventures that develop their $\mathrm{MO}$ resources and align these with their intra-firm resource coordination competencies will fully realize the export sales benefits of their EO activities.

Keywords: Export entrepreneurial orientation Export market orientation Resource coordination capability Export sales performance

1. Introduction International business literature identifies export entrepreneurial orientation (EO) and export market orientation (MO) as important strategic orientations that are beneficial for sales performance in export markets (e.g., Boso, Cadogan, \& Story, 2012; Murray, Gao, \& Kotabe, 2011). Specifically, EO is a market-driving explorative capability (Hughes, Hughes, \& Morgan, 2007) "characterized by search, discovery, experimentation, risk taking and innovation [in foreign markets]" (He \& Wong, 2004, p. 481). MO is an informationprocessing capability that draws heavily on a market-driven exploitative logic to fuel business success (Jaworski, Kohli, \& Sahay, 2000). As an exploitative behavior, MO provides a buffer against the shocks and risks associated with EO. Taken together, EO and MO play complementary roles in shaping firm sales performance (Boso et al., 2012).

The findings of past research attempts to explain the relationship between the two orientations and sales performance has so far been equivocal (e.g., Bhuian, Menguc, \& Bell, 2005; Cadogan, Kuivalainen, \& Sundqvist, 2009). Some study results show a positive relationship, while others are negative (e.g., Balabanis \& Katsikea, 2003; Boso et al., 2012; Murray et al., 2011). Studies examining non-linear relationships also show results that are divergent and unclear (e.g., Bhuian et al., 2005; Cadogan et al., 2009). Thus, whether the impacts of EO and MO on sales performance are linear or non-linear remains an unsettled issue (Lisboa, Skarmeas, \& Saridakis, 2016) and non-linear paths dependent on environmental conditions lack research.

This study argues that a lack of precision regarding the form of the relationship between EO/MO and export performance partly explains the diversity of findings in the literature. Unlike previous research that assumes linear relationships between the orientations and sales performance, this study posits the possibility of non-linear relationships. Drawing insights from relevant prior studies (e.g., Bhuian et al., 2005; Cadogan \& Cui, 2004; Cadogan et al., 2009), this study calls for a test for intraorganizational structural contingencies that would result in variations to the shape of 
the curvilinear relationships between the two orientations and export sales performance.

Accordingly, this study investigates whether optimal levels of export EO and $\mathrm{MO}$ behaviors (henceforth export EOB and export MOB) accurately predict export sales performance under differing levels of export coordination flexibility. Export coordination flexibility is defined as an organizational structural characteristic that embodies firms' abilities to redefine, reconfigure, and redeploy resource chains to meet overall organizational goals, and to successfully react to opportunities and challenges posed by the environment (Johnson, Lee, \& Saini, 2003; Sanchez, 1995). Evidence shows that firms must do more than simply develop greater (or lower) levels of EOBs unless they simultaneously have the structural flexibility to produce and deliver on superior customer values (Atuahene-Gima \& Ko, 2001; Sanchez, 1995). Likewise, the benefits of market-oriented insights are limited for a firm that does not have the flexibility to integrate new market opportunities into existing marketing strategies (Jaworski et al., 2000). This study extends existing knowledge by examining the export resource flexibility contingencies between export EOB and export $\mathrm{MOB}$ and performance, thereby generating new information about how and when export strategies predict export performance.

\section{Theoretical framework and hypotheses}

Export entrepreneurship research suggests that export EOB enables firms to secure superior sales performance in their export markets (e.g., Balabanis \& Katsikea, 2003). Amajor logic supporting this positive relationship is that entrepreneurialoriented exporting firms benefit frompioneering and first-mover advantages that allow themto explore new market opportunities ahead of the competition. The export literature supports the claim that export MOB firms generate superior sales performance in their exportmarkets because they prioritize export customer intelligence acquisition, sharing, and usage, and are therefore more capable of providing solutions to customers' expressed and latent needs (Murray et al., 2011). Prior research implies a linear association between the two orientations and export sales performance.

Unlike prior research, this study argues that export EOB and export MOB have conditional effects on export sales performance. Previous studies ignored several possibilities: (1) The two orientations are expensive to develop and maintain, implying that firms need optimal levels of the two orientations. (2) The two orientations may compete for scarce resources and firms may be inclined to choose between the two. (3) Firms may over-invest (or under-invest) in either one or both orientations. (4) Other strategic orientations (e.g., technology orientation or sales orientation) may work to drive performance, thereby drawing the attention ofmanagers. Also missing fromprevious research is the possibility of internal structural contingencies (here coordination flexibility) to facilitate or inhibit the impact of the two orientations on export sales performance. These arguments lead to the development of a proposed conceptual model (see Fig. 1) and the hypotheses that follow.

\subsection{Form of relationship between export EO/MO and export performance}


In this study, it is argued that firms need to continuously pursue greater innovation, constructive risk-taking, and new market opportunities ahead of competitors (i.e., high levels of EOB). Higher levels of export EOB would result in firms being everready to offer incremental and novel products in export markets, offerings that might enable firms to continuously shape the market to their advantage. With growing levels of EOB in export operations, the behaviors of export personnel are geared towards increased opportunity identification and exploration aimed at shaping and restructuring export markets to generate superior value. For such entrepreneurial activities to remain the dominant orientationwithin an export unit, they need to be repeatedly promoted and applied (Hughes et al., 2007). Findings in the export literature support this view: "The adoption of an entrepreneurial posture is something that profit-maximising firms have to...pursue actively for their export operations regardless the conditions of their markets" (Balabanis \& Katsikea, 2003, p. 246); and Kropp, Lindsay, \& Shoham (2006) urge export managers "to ensure that there are ongoing programs... to stimulate, enhance and encourage [entrepreneurial orientation]" (p. 514).

High performance is expected as a result of greater investments in export EOB. According to Bhuian et al. (2005), firms' levels of EOB have positive implications for business performance for a number of reasons. At higher levels of export EOB, it is likely that a firm would take greater risks to proactively launch greater number of innovations and explore new market opportunities. While greater EOB can help a firm launch new innovations and explore alternative opportunities requires substantial resource investments, the benefit of pursuing higher levels of EOB is likely to exceed this resource investment cost. The logic is that higher EOB levels increase a firm's ability to launch new innovations and enhance its motivation to explore entry opportunities (Lumpkin and Dess, 1996). The new innovations launched and the new entry opportunities explored as a result of greater export EOB may boost a firm's export decision making processes and as a result enhance its export performance. Thus, we contend that variations in export performance is a function of increasing levels of export EOB.

H1. A J-shaped relationship exists between export EOB and export performance.

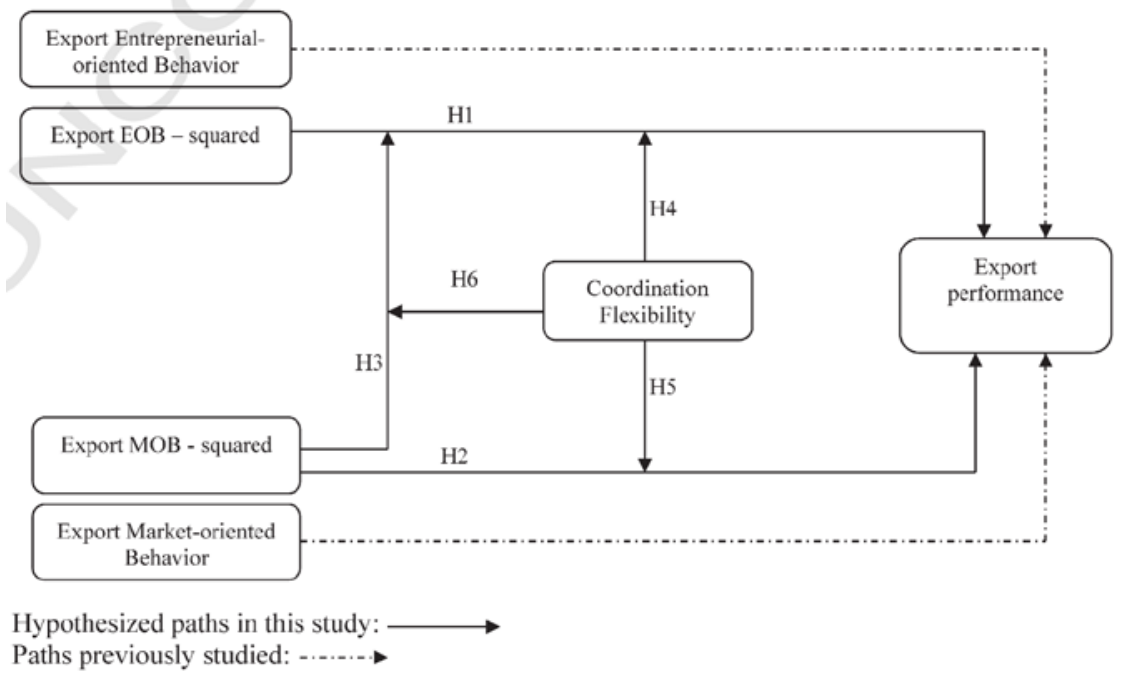


March (1991) argues that too much exploitative activity might lead to structural inertia and reduce firms' abilities to adapt to emerging market opportunities. This reasoning is emphasized in the work of He \& Wong (2004), who found that too much market-driven behavior might "reduce the speed at which existing competencies are improved and refined" (p. 482). Christensen \& Bower (1996) also argued that too much market-oriented activity stifles innovation and inhibits a firm's ability to adapt to future opportunities. Indeed, the export literature shows that export MOB has an inverted U-shape relationship with aspects of export sales performance. Cadogan et al. (2009) observed that "firms with high levels of [export MOB] may have gone beyond some sweet spot and may well be on the downslope (i.e., have [export MOB] levels that are higher than some optimal value in terms of export sales success)" ( $p$. 83). Similar results are reported in other studies (see Atuahene-Gima et al., 2005; Cadogan \& Cui, 2004).

H2. An inverted U-shaped relationship exists between exportMOB and export performance.

The literature advocates the need for firms to combine theirmarketdriven activitieswith theirmarket-driving behaviors to ensure that protective cash-generating strategies are effectively aligned with new product-market strategies to maximize performance (Atuahene-Gima \& Ko, 2001; He \& Wong, 2004). However, this strategy prescription fails to recognize that (1) exporters operate with tight budgets in complex and generally less-tested overseas environments, and (2) simultaneous implementation of the two market-based activities can be expensive and could mean taking resources away from other equally productive orientations (e.g., technological orientation, and sales orientation). Thus, to achieve satisfactory sales performance from EOB, a moderate level of export MOB (unlike low and high levels) would be optimal. For example, the literature cautions firms to avoid unbridled entrepreneurial zeal while also increasingly focusing on responding to current market needs

(Christensen \& Bower, 1996). To a certain point, a rising level of MOB would result in a poor performance outcome of EOB, as this increase has the potential to overextend firm resources. In fact, the organizational ambidexterity literature emphasizes the potential tension between entrepreneurial- and market-oriented activities, suggesting that firms should seek best fit between the two strategic orientations to boost sales performance (e.g., Raisch \& Birkinshaw, 2008).

Chandler (1996) argues that overly entrenched capabilities and processes can cause strategic inertia, and Atuahene-Gima \& Ko (2001) suggest that firms should seek appropriate levels of MOB in which entrepreneurship can flourish (see also Boso et al., 2012). This study argues from a resource usage perspective that a simultaneous implementation of both orientations can be expensive, especially for new resourceconstrained international ventures. The literature suggests thatMO activities have higher short-termreturns that dominate other strategic behaviors in the early years of new businesses (Hughes et al., 2007). Failure of a major entrepreneurial initiativemight risk the survival of newventures (He \&Wong, 2004).

H3. The J-shaped relationship between EOB and export performance is greatest at moderate levels of MOB.

\subsection{Export coordination flexibility as a moderator}


Gibson \& Birkinshaw (2004) identified the need to build flexible structural mechanisms "to cope with the competing demands faced by organizations for alignment and adaptability" (p. 211) to environmental changes. Additionally, Sanchez (1995) argues that creative firms connect, coordinate, and synchronize functional units to take advantage of new product-market opportunities. Sanchez (1995) further stresses that new product-market development strategies are facilitated when firms invest in "flexibility in coordinating the use of product creation resources" (p. 140). Exporters in particular require flexibility in system reprogramming and reconfiguration, modification flexibility, changeover flexibility and responsiveness flexibility in order to deal with demand variability in export markets (c.f. Sanchez, 1995). For example, an exporter with a rigid production system will be slow in adapting internal processes to take advantage of new exportmarket opportunities, and thus, the optimal values of new market opportunities discovered will not be realized. The literature on organizational bureaucracy and routine emphasizes the roles of structural adaptability, involvement, andmutation in supporting entrepreneurial initiatives and in effectively taking advantage of emerging market opportunities (Feldman \& Pentland, 2003). Accordingly, in the current study it is argued that the benefits of firms' export market-driving exploratory activities (i.e., their export EOBs) increase in the presence of high levels of export coordination flexibility.

H4. The J-shaped relationship between export EOB and export performance becomes greater in magnitude as coordination flexibility increases.

The impact of export MOB on export performance is predicated on the informational advantages EOB provides firms (Cadogan et al., 2009). However, firms need greater levels of coordination flexibility in order to benefit fully from the performance advantages EOB brings. Firms need structural stability to dealwith the certainties of themarket (Feldman \& Pentland, 2003; He \&Wong, 2004). Export MOB embodies refinement of existing market knowledge and "[relies] on the processes of search, collection and assimilation" (Hughes et al., 2007, p. 364). Because highlymarketoriented firms rely onmarket-intelligence acquisition, if they are to respond quickly to market demands they need stable information processing routines and procedures, not fluid structures.

H5. The inverted U-shaped relationship between export MOB and export performance becomes greater in magnitude when export coordination flexibility increases.

The literature treats $\mathrm{EOB}$ and $\mathrm{MOB}$ as complementary orientations that generate synergistic outcomes (Atuahene-Gima \& Ko, 2001). Accordingly, firms are encouraged to invest in structural mechanisms that facilitate integration of the two orientations (Raisch \& Birkinshaw, 2008). Coordination flexibility ensures that firms are nimble and able tomore rapidly take advantage of changes occurring in target market environments. A lack of coordination flexibility would mean that firms may be tempted to invest more in marketdriven activities for short-run rewards at the expense of a more long-term market-driving activity (Cadogan et al., 2009). A lack of coordination flexibility may also mean that a firm's chosen strategic paths are limited, resulting in a struggle to respond rapidly to a changing market environment. In fact, 
coordination flexibility facilitates a firm's ability to respond quickly to market dynamics and fosters effective use of resources to create superior customer value. While export EOB offers market-driving capability and export MOB brings firms access to existing market knowledge, firms are able to enhance their performance when they strengthen their ability to harmonize different units to redefine, reconfigure, and redeploy resources to take advantage of new and existing market opportunities generated by $\mathrm{EO}$ and $\mathrm{MO}$ activities. To this end coordination flexibility may be seen as a rebalancing capability that helps maximize the value of the two orientations.

H6. The moderating effect of export MOB on the J-shaped relationship between export EOB and export performance increases in strength as coordination flexibility increases.

\section{Methodology}

\subsection{Sample and data collection}

The study tested the proposed model on primary data from exporting firms in the United Kingdom. The study uses Bureau van Dijk database to randomly select 830 senior export managers directly involved in their firms' strategic export decisionmaking for the study. Ultimately, the study obtains 212 useable responses, a $26 \%$ response rate. The firms operate in computers, textiles and garments, food and beverages, crafts, agro-processing, security, and financial services industries. The firms averaged 656 employees and their export revenues accounted for $40.67 \%$ of total annual sales. Non-response bias was assessed with Armstrong \& Overton's (1977) extrapolation method, and results showed no major non-response bias issues. To minimize common method bias threats, 12 months after the first study, the study collected a second-point export performance data from finance managers in the 212 firms previously surveyed. One hundred ninety-one of the 212 firms provided valid responses on their export performance. Subsequently, the study followed the Van Bruggen, Lilien, \& Kacker (2002) interrater agreement index (rWG) to compute for each of the export performance measures from the two informant groups. The lowest rWG index for the entire set of items was 0.80 . The study then aggregated the responses from the two informant groups to obtain a single group composite value for the export performance items (Van Bruggen et al., 2002), and used the combined data in further analyses.

\subsection{Measures}

The study based assessment of export EOB on the Boso et al. (2012) scale in which export EOB was conceptualized as comprising of export innovativeness (made up of product innovation intensity and product innovation novelty dimensions), exportmarket risk-taking, exportmarket proactiveness, export market competitive aggressiveness, and export autonomy. To measure export MOB, the study used items from Cadogan et al. (2009) to assess the three behavioral dimensions of the export MOB construct: export intelligence generation, dissemination, and responsiveness. To measure export coordination flexibility, the study developed new measures based on the definition of coordination flexibility proposed by Sanchez (1995). Accordingly, the study operationalized export coordination flexibility as the ability of firms to redefine their product-market strategies and to reconfigure and 
redeploy resource chains to implement export market strategies. The study drew on Cadogan et al. (2009) to assess export performance as the extent to which the expectations of the firms' export unit objectives were met in terms of exportmarket share, export sales volume, and export sales growth. Further, the study measured and modeled a number of control variables including firmsize, measured by the number of fulltime employees, and industry type, measured as a categorical variable (1 = manufacturing, 2 = services) (Wang, 2008). Additionally, the study created and included lower-order interaction terms in the analyses (obtain details of the terms from the corresponding author upon request.)

\section{Analysis}

\subsection{Assessment of measures}

The study undertook a confirmatory factor analysis (CFA) of allmeasures using LISREL 8.54 and the maximum likelihood estimation procedure. The study then assessed exact model fit using the chi-square $(x 2)$ test, and examined a number of approximate fit heuristics to provide additional information on model fit. The CFAmodel achieved excellent fit to the data, with a non-significant chi-square value $(X 2 / D F=126.21 / 104=1.21)$. All the other fit heuristicswerewellwithin normal cut-off ranges: RMSEA=0.03; NNFI=0.99; and $\mathrm{CFI}=0.99$. Composite reliability and discriminant validity of all constructs exceeded the minimum cut-off criteria of 0.60 and 0.50 respectively. The average variances extracted were larger than the shared variances between constructs, indicating satisfactory discriminant validity (Fornell \& Larker, 1981). Table 1 displays the correlation matrix, reliability and discriminant validity tests for the study's constructs.

\subsection{Structural model assessment}

To test the hypotheses, the study created quadratic and multiplicative indicants in line with the literature (e.g., Ping, 1995). First, the study computed quadratic terms for export EOB and export MOB by squaring their respective scores.

Second,multiplicative terms for Export EOB-squared $\times$ Export MOB-squared was calculated. Third, Export EOB-squared $\times$ Flexibility, Export MOB-squared $\times$ Flexibility, and Export EOB-squared $\times$ Export MOB-squared $\times$ Flexibility scores were created. Finally, following recommended procedures (e.g., Aiken \& West, 1991), the study created lower-order interactions, and used these interaction terms togetherwith direct effects, firm size, and an industry dummy as control variables. The study orthogonalized all variables that were involved in multiplicative and quadratic interactions. The orthogonalization helped reduce the potential of multicollinearity problems arising from the introduction of multiplicative and quadratic terms in the structural model. Consequently, the study estimated the structural model in LISREL 8.72with covariancematrix as input variable and maximum likelihood method as the model estimation method.

\section{Results}

The study estimated two nested structural models. A restricted model was estimated in which only main effect paths were estimated. The fit statistics for the unrestrictedmodelwere superior to the restricted model, as can be seen in Table 2 . 
Details of the path estimates and tvalues for the unrestricted model are provided in Table 2, and, for easy interpretation, Fig. 2 displays surface plots for the estimated model results, which is obtained using the approach advocated by Aiken and West (1991).

The study's hypotheses are rejected if the paths linking export EOB and export sales performance are negative and significant, and export MOB and export sales performance are positive and significant, and all the hypothesized paths are nonsignificant. As can be seen in Table 2, the EOB $\rightarrow$ performance path estimate is positive and significant $(\mathrm{y}=0.17 ; \mathrm{t}=2.41)$. In addition, the MOB $\rightarrow$ performance parameter is positive and significant $(\gamma=0.31 ; t=3.91)$. However, the study provides support for $\mathrm{H} 1$ because the EOB-squared $\rightarrow$ performance path estimate is positive and significant $(y=0.18 ; t=2.02)$. This shows that $E O B$ has a $\mathrm{J}$-shaped relationship with export performance. Because $\mathrm{H} 2$ is nested within $\mathrm{H} 3, \mathrm{H} 5$, and $\mathrm{H} 6$, support is provided for $\mathrm{H} 2$ if any one of the three high-order parameters is significant. As Table 2 shows, the MOBsquared $\rightarrow$ performance path is non-significant $(\gamma=0.02 ; t=$ 0.23). However, other hypotheses are supported. Specifically, path estimates for exportMOB-squared $\times$ export EOB-squared $\rightarrow$ performance are negative and significant $(\mathrm{y}=-0.16 ; \mathrm{t}=-1.78)$, indicating that MOB has an inverted $\mathrm{U}$-shaped relationship with export performance when export EOB takes on higher values. The negative and significant path for export MOB-squared $\times$ export EOB-squared $\rightarrow$ performance also provides support for $\mathrm{H} 3$.

Table 1 Descriptive statistics, inter-construct correlations, and discriminant validity tests.

\begin{tabular}{|c|c|c|c|c|c|c|c|}
\hline & Variables & 1 & 2 & 3 & 4 & 5 & 6 \\
\hline 1. & Export EOB & & & & & & \\
\hline 2. & $\begin{array}{l}\text { Export } \\
\text { performance }\end{array}$ & 0.38 & & & & & \\
\hline 3. & Flexibility & 0.11 & 0.08 & & & & \\
\hline 4. & Export MOB & 0.44 & 0.36 & 0.01 & & & \\
\hline 5. & Firm size & 0.36 & 0.04 & -0.06 & 0.09 & & \\
\hline \multirow[t]{5}{*}{6.} & $\begin{array}{l}\text { Industry } \\
\text { dummy }\end{array}$ & -0.07 & -0.05 & 0.08 & -0.02 & 0.08 & \\
\hline & $\begin{array}{l}\text { Average } \\
\text { variance } \\
\text { extracted }\end{array}$ & 0.70 & 0.64 & 0.56 & 0.55 & na & na \\
\hline & $\begin{array}{l}\text { Composite } \\
\text { reliability }\end{array}$ & 0.87 & 0.81 & 0.74 & 0.78 & na & na \\
\hline & Mean & 4.57 & 4.67 & 4.62 & 5.34 & 4.60 & 1.16 \\
\hline & $\begin{array}{l}\text { Standard } \\
\text { deviation }\end{array}$ & 0.84 & 1.04 & 1.11 & 0.80 & 1.29 & 0.36 \\
\hline
\end{tabular}

The study predicts in $\mathrm{H} 4$ that coordination flexibility moderates the path linking EOBsquared and export performance. The result of the export EOB-squared $x$ coordination flexibility $\rightarrow$ performance path estimate is positive and significant $(\gamma=$ $0.13 ; t=1.78)$, indicating support for $\mathrm{H} 4$. This finding shows that the non-linear relationship 

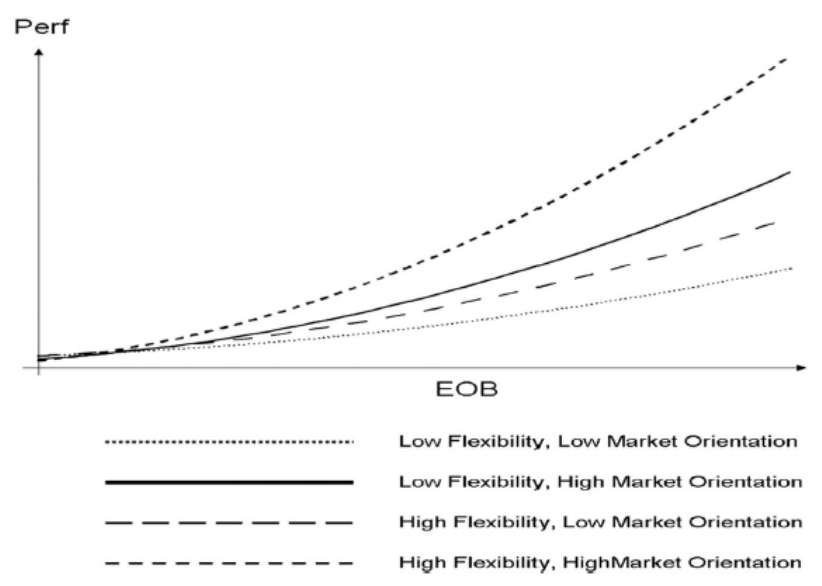

Fig. 2. Results of the quadratic and moderating effect relationships.

between EOB and sales performance becomesmore positivewhen coordination flexibility increases in magnitude. The study specifies in $\mathrm{H} 5$ that the inverted $\mathrm{U}$-shape relationship between $\mathrm{MOB}$ and performance is more negative when coordination flexibility is greater. The study finds support for $\mathrm{H} 5(\gamma=-0.16$; $t=-2.11)$ because the inverted U-shape relationship between MOB and performance becomes more negative when coordination flexibility increases in magnitude. $\mathrm{H} 6$ argues that the combined effect of EOB and of MOB on export performance is more positive as coordination flexibility increases. Support is provided for $\mathrm{H} 6$ because the parameter estimate for $\mathrm{H} 6(\gamma=0.13 ; t=1.98)$ is significant at $5 \%$ levels, suggesting that the relationship between export EOB and export performance is strengthened when firms are moderately market-oriented and when levels of coordination flexibility are high (see Fig. 2).

6. Discussion, conclusion, and future research directions 
The international business literature encourages firms to develop high levels of export EOB and export MOB to boost their sales performance in export markets. However, this study suggests that while export EOB and MOB activities are important for export success, what is more important is how firms can maximize the economic value of these two strategic orientations. While some empirical works have explored the complexity of the relationship between some of the orientations (i.e., EO) and performance (e.g., Lisboa et al., 2016), this extends prior research by exploring the form of the relationship between EOB and MOB and export performance. By so doing, this study exposes the importance of paying attention to the optimum levels of the two orientations, and to the moderating role of structural contingencies in conditioning the performance outcomes of the orientations.

Prior research suggests that increasing levels of export EOB and export $M O B$ contribute to increased export sales performance (e.g., Boso et al., 2012; Murray et al., 2011). This study goes a step further to argue that exporting firms should not only focus efforts on developing increasing levels of EOB and MOB activities but pay greater attention to how optimal levels of these orientations can be achieved and how such activities can be leveraged to enhance export success. This study finds that while export EOB and MOB are positively associated with export performance, the form of that relationship is more complex than reported in prior research, especially when boundary conditions are more carefully examined. Importantly, evidence shows that the relationship between export EOB and export sales performance is J-shaped, and becomes strengthenedwhen firms aremoderatelymarket-oriented and levels of coordination flexibility are high, suggesting that firms need to work towards achieving best fit between EOB and MOB activities while also taking into account structural contingencies that leverage the performance consequences of the two orientations.

To this end, this study suggests that the ability of exporting firms to synchronize export market strategies, reconfigure, and redeploy chains of strategic resources can help leverage existing capabilities to explore new export market opportunities. Greater flexibility in reorganizing and redeploying major resources such as key personnel, financial capital, and R\&D, allows managers to take greater advantage of new market knowledge and opportunities that are developed through entrepreneurial-oriented strategies than when managers are rigid about the movement of such resources. The value of an entrepreneurial strategy is greater when that strategy is carefully leveraged and supported with flexible coordination activities. This study also shows the value of creating synergy fromthe integration of EOB andMOB activities. Findings suggest thatmanagers enhance export performance when they pursue exporting strategies that are predicated on a blend of optimal levels of EOB and MOB activities supported by appropriate flexibility coordination policies. This is critical because successful market-seeking activities depend on how exporters manage new and existing market knowledge (Hughes et al., 2007). Firms that are successful in building a diverse market knowledge base drawn from both existing and new information can expand their competitive range (He \& Wong, 2004). Market-driving EO activities and market-driven MO activities are inseparable (Jaworski et al., 2000; Raisch \& Birkinshaw, 2008), but because these activities can be expensive to develop and maintain, exporters need to combine the interdependent processes optimally, while maintaining high levels of flexibility in their use, to generate greater sales performance. 
A core future research direction revolves around learning more aboutmajor antecedents to implementation of EOB andMOB export operation activities such as key structural and managerial mechanisms that foster or inhibit the implementation of the two orientations. Additionally, in today's increasingly turbulent and dynamic global marketplace, future research should also examine external environment and intra-firmresourcemoderators on the effects of EOB andMOB on export performance. This study relies on self-reported data of exporting firms in the United Kingdom. Future research relying on objective datasets may help track the actual variations in $\mathrm{EO}$ and $\mathrm{MO}$ behaviors and their effects on export performance across levels of structural contingencies. Given that the two orientations are examined from an exporting perspective, investigating the relationships in multi-national studies will help broaden existing knowledge on any country-level contingencies that may shape export performance outcomes of the two strategic orientations.

\section{References}

Aiken, L. S., \& West, S. G. (1991). Multiple regression: Testing and interpreting interactions. Thousand Oaks: Sage.

Armstrong, J. S., \& Overton, T. S. (1977). Estimating nonresponse bias in mail surveys. Journal of Marketing Research, 14(3), 396-402.

Atuahene-Gima, K., \& Ko, A. (2001). An empirical investigation of the effect of market orientation and entrepreneurship orientation alignment on product innovation. Organization Science, 12, 54-74.

Atuahene-Gima, K., Slater, S. F., \& Olson, E.M. (2005). Th e contingent value of responsive and proactive market orientations for new product program performance. Journal of Product Innovation Management, 22(6), 464-482.

Balabanis, G. I., \& Katsikea, E. S. (2003). Being an entrepreneurial exporter: Does it pay? International Business Review, 12(2), 233-252.

Bhuian, S. N.,Menguc, B., \& Bell, S. J. (2005). Just entrepreneurial enough: Themoderating effect of entrepreneurship on the relationship between market orientation and performance. Journal of Business Research, 58, 9-17.

Boso, N., Cadogan, J. W., \& Story, V. M. (2012). Complementary effect of entrepreneurial and market orientations on export new product success under differing levels of competitive intensity and financial capital. International Business Review, 21(4), 667-681.

Cadogan, J. W., \& Cui, C. C. (2004). Chinese export agents' adoption of export marketoriented behaviours: Measurement and performance relationship. Journal of Asia Pacific Marketing, 3(2/3), 21-37.

Cadogan, J. W., Kuivalainen, O., \& Sundqvist, S. (2009). Export market-oriented behavior and export performance: Quadratic and moderating effects under differing degrees of market dynamism and internationalization. Journal of International Marketing, 17(4), 71-89.

Chandler, G. N. (1996). Business similarity as a moderator of the relationship between pre-ownership experience and venture performance. Entrepreneurship: Theory and Practice, 20(3), 51-66.

Christensen, C. M., \& Bower, J. L. (1996). Customer power, strategic investment, and the failure of leading firms. Strategic Management Journal, 17, 197-218. 
Feldman,M. S., \& Pentland, B. T. (2003). Reconceptualizing organizational routines as a source of flexibility and change. Administrative Science Quarterly, 48(1), 94118.

Fornell, C., \& Larcker, D. F. (1981). Structural equation models with unobservable variables and measurement error: Algebra and statistics. Journal of Marketing Research, 18(3), 362-368.

Gibson, C. B., \& Birkinshaw, J. (2004). The antecedents, consequences, and mediating role of organizational ambidexterity. Academy of Management Journal, 47, 209-226.

He, Z., \&Wong, P. (2004). Exploration vs. exploitation: An empirical test of the ambidexterity hypothesis. Organization Science, 15(4), 481-494.

Hughes, M., Hughes, P., \& Morgan, R. E. (2007). Exploitative learning and entrepreneurial orientation alignment in emerging young firms: Implications for market and response performance. British Journal of Management, 18, 359-375. Jaworski, B., Kohli, A. K., \& Sahay, A. (2000). Market-driven versus drivingmarkets. Journal of the Academy of Marketing Science, 28, 45-54.

Johnson, J. L., Lee, R. P., \& Saini, A. (2003). Market-focused strategic flexibility: Conceptual advances and an integrative model. Journal of the Academy of Marketing Science, 31(1), 74-89.

Kropp, F., Lindsay, N. J., \& Shoham, A. (2006). Entrepreneurial,market, and learning orientations and international entrepreneurial business venture performance in South African firms. International Marketing Review, 23(5), 504-523.

Lisboa, A., Skarmeas, D., \& Saridakis, C. (2016). Entrepreneurial orientation pathways to performance: A fuzzy-set analysis. Journal of Business Research, 69(4), 1319-1324.

March, J. G. (1991). Exploration and exploitation in organizational learning. Organization Science, 2(1), 71-87.

Murray, J. Y., Gao, G. Y., \& Kotabe, M. (2011). Market orientation and performance of export ventures: The process through marketing capabilities and competitive advantages. Journal of the Academy of Marketing Science, 39(2), 252-269.

Ping, R. A., Jr. (1995). A parsimonious estimation technique for interaction and quadratic latent variables. Journal of Marketing Research, 32(August), 336-347. Raisch, S., \& Birkinshaw, J. (2008). Organizational ambidexterity: Antecedents, outcomes, and moderators. Journal of Management, 34(3), 375-409.

Sanchez, R. (1995). Strategic flexibility in product competition. Strategic Management Journal, 16(Summer), 135-159.

Van Bruggen, G. H., Lilien, G. L., \& Kacker, M. (2002). Informants in organizationalmarketing research: Why use multiple informants and how to aggregate responses. Journal of Marketing Research, 34, 469-478.

Wang, C. L. (2008). Entrepreneurial orientation, learning orientation, and firm performance. Entrepreneurship: Theory and Practice, 32(4), 635-657. 